\title{
Evaluation of carrying capacity and territorial environmental sustainability
}

\author{
Giuseppe Ruggiero, ${ }^{1}$ Giuseppe Verdiani, ${ }^{1}$ Stefano Dal Sasso² \\ ${ }^{1}$ Department of Agro-Environmental Sciences (DISAAT), University of Bari, Italy; \\ ${ }^{2}$ Freelance Civil Engineer
}

\begin{abstract}
Land use has a great impact on environmental quality, use of resources, state of ecosystems and socio-economic development. Land use can be considered sustainable if the environmental pressures of human activities do not exceed the ecological carrying capacity. A scientific knowledge of the capability of ecosystems to provide resources and absorb waste is a useful and innovative means of supporting territorial planning. This study examines the area of the Province of Bari to estimate the ecosystems' carrying capacity, and compare it with the current environmental pressures exerted by human activities. The adapted methodology identified the environmentally sustainable level for one province.
\end{abstract}

\section{Introduction}

Sustainable development aims to meet the needs of the present generations without compromising the ability of future generations to meet their own needs (World Commission of Environment and Development, 1987). The transformation of land use plays an important role in sustainable development since it involves changes in the environment and landscape. In fact, land use has a great impact on environmental quality, use of resources, state of ecosystems and socioeconomic development (Steiner et al., 2000; Marull et al., 2007). The

Correspondence: Giuseppe Verdiani, Department of Agro-Environmental Sciences (DISAAT), University of Bari, via Amendola 165/A 70126 Bari, Italy. Tel/Fax: +39.0805442964.

Key words: ecosystem capacity, environmental pressures, land use.

Acknowledgements: the present study has been carried out under the Project Research of the University of Bari Criteria for assessing the environmental carrying capacity of the rural environment.

Contributions: the authors contributed equally.

Received for publication: 14 May 2012

Accepted for publication: 3 August 2012.

(C) Copyright G. Ruggiero et al., 2012

Licensee PAGEPress, Italy

Journal of Agricultural Engineering 2012; XLIII:e10

doi:10.4081/jae.2012.e10

This article is distributed under the terms of the Creative Commons Attribution Noncommercial License (by-nc 3.0) which permits any noncommercial use, distribution, and reproduction in any medium, provided the original author(s) and source are credited. anthropic activities exerting pressures on the environment and modifying the status of natural resources, therefore, have an impact on ecosystems and human health. The pressures exerted by human activities on ecosystem structure and function (Scheffer et al., 2001) are the production of pollutants (waste, wastewater and gas emissions) and the consumption of renewable and non-renewable resources (Bettini, 1986; Rajaran and Das, 2011). The consumption of natural resources and emission of pollutants modify environmental status and its relationships with chemical, physical landscaping, architectural and agricultural factors. These changes in environmental status caused by human activities in the area, and the implementation of plans, programmes and projects has been termed environmental impact by the United Nations Economic Commission for Europe in the Espoo Convention (1991). A deeper knowledge of the relationship between environmental pressures and impact may allow technical interventions and planning of land use to be implemented aimed at achieving sustainable development to be implemented (Dal Sasso, 2001; Holden, 2004).

Land use can be considered sustainable if the environmental pressures of human activities do not exceed the limited capacity of ecosystems to provide resources and absorb waste without compromising their quantity and quality (Graymore et al., 2010). In this way, ecosystems ensure the productivity of resources and services essential to future generations (Daily, 1997). In fact, the three conditions set by Daly (1991) to ensure sustainable development are: i) the accrual of the use of renewable resources shall not exceed the related accrued regeneration; ii) the accrual of the use of non-renewable resources shall not exceed the speed of development of renewable substitutes; iii) the emission of pollutants shall not exceed the absorption capacity of the environment.

Methods to assess the environmental sustainability of land use can identify and help implement solutions to protect the ecosystem and minimise the negative environmental impact at the source (Cai et al., 2003; Morrissey et al., 2006). A method for assessing the sustainability on a regional scale should provide quantitative information about sustainability and the impact of decisions made concerning land use. The most common methods for assessing the sustainability on a regional scale are: i) emergetic analysis; ii) comparing ecological footprint and biocapacity; iii) territorial environmental balance; iv) comparing environmental pressures and carrying capacity.

The methods listed for assessing sustainability are based on the use of indicators highlighting the economic, social and environmental aspects (Castoldi and Bechini, 2010), and to effectively describe the pressures exerted by human activities on natural resources and the impact on ecosystems (Dale and Beyeler, 2001; Niemi and McDonald, 2004). The indicators are, in fact, analytical and interpretative tools of ecological dynamics (Wiggering and Muller, 2004) that can represent any level of complexity (Turnhout et al., 2007), therefore providing a useful guide for the implementation of more advanced criteria for land use planning (Colantonio and Galli, 2006). Indicators can be compared with regulatory limit values, objectives (Van Cauwenbergh et al., 2007), sustainability thresholds and intervals (Wiek and Binder, 2005; Zahm et al., 2006). 
Emergy analysis is based on the use a set of thermodynamic indicators of sustainability expressed in terms of equivalent solar energy (solar emjoule) that make scientific assessments of the interaction between natural and productive economic systems (Franzese et al., 2003). Emergy (Odum, 1996) is a thermodynamic quantity that represents the work done by the environment to generate ecosystem services that living systems must use optimising the outputs (Ulgiani et al., 1994).

The ecological footprint is an aggregate and synthetic indicator developed by Wackernagel and Rees (1996) that represents the ecologically productive area needed to produce the resources consumed and to absorb the waste generated by humans (Monfreda et al., 2004). The area can effectively represent and communicate the finiteness of the planet Earth and its ability to generate resources (Wackernagel and Rees, 1997). The comparison between the ecological footprint and the effective presence of ecologically productive land (biocapacity) identifies the ecological deficit or surplus of a local context. Currently, the Italian biocapacity is able to meet only $34.8 \%$ of the ecological footprint leaving an ecological deficit amounting to $65.2 \%$ (Tiezzi and Marchetti, 2003). The ecological footprint recognises the role of natural capital but does not take into account the regenerative capacity of the resources. To overcome this limitation, the concept of a three-dimensional ecological footprint has been recently introduced. It estimates the time required for regeneration of the natural resources consumed annually (Niccolucci et al., 2009).

The territorial environmental balance is a dynamic spatial analytical tool developed by the Technical Research Centre of Finland in the 1990s (Harmaajarvi, 2000) that evaluates the effects of land use on environmental equilibrium through the use of indicators (Maffiotti et al., 2008).

The comparison between environmental pressures from human activities produced at defined sites and the environmental carrying capacity is the most important and significant procedure to assess sustainability on a regional scale (Yin et al., 2010). The carrying capacity is a concept rooted in demography as applied to ecology and biology (Clarke, 2002), and was introduced by Odum (1988) as the number of individuals that can be sustained indefinitely in a given habitat without causing damage to the productivity of ecosystem on which their livelihoods depend. This concept has been extended to the environmental sector and it has been defined as the maximum consumption of natural resources and waste discharge that can be supported in an area without compromising the ecosystem status (Khanna et al., 1999; Oh et al., 2005).

Numerous attempts to quantify the exact carrying capacity have been conducted but there are still no effective and efficient methods (Graymore et al., 2010; Lane, 2010) because of practical problems associated with its measurement (Papageorgiou and Brotherton, 1999) and the complexity of ecosystem dynamics (Holling et al., 2000). Most of the existing methodologies for determining the environmental carrying capacity of a territory are based on estimated flows of resources (water, energy, land) and waste (emissions, solid waste, wastewater) that affect the environmental status (Wackernagel and Rees, 1996; Tang and Ye, 1998; Khanna et al., 1999; Yu and Mao, 2002; Clarke, 2002; Komatsu et al., 2005; Oh et al., 2005; Graymore et al., 2010; Yin et al., 2010; Liu and Borthwick, 2011). These flows are defined as critical flows or sustainability thresholds and can be estimated through complex operations based on policy environmental standards and the capacity of ecosystems to provide resources and assimilate the wastes (Kang and Xu, 2010; Dal Sasso, 2001). The determination of the total carrying capacity cannot be expressed only through the individual sustainability thresholds, but must also take into account the connections between them (Komatsu et al., 2005; Yin et al., 2010).

The comparison between the environmental pressures exerted by human activities and their sustainability thresholds can be made using indicators to assess current environmental sustainability or that expected in the future by land use planning (Graymore et al., 2010; Dal Sasso, 2001). The results of the comparison between pressure and environmental sustainability thresholds based on carrying capacity can, therefore, give useful information for planning, environmental management and the Strategic Environmental Assessment (SEA) (Godschalk and Parker, 1975; Baldwin, 1985; Ng and Obbard, 2004).

The objective of this study is to assess the environmental sustainability on a regional scale by comparing the environmental pressures and the estimated carrying capacity in the study area (Province of Bari). An understanding of the environmental sustainability levels on a regional scale is the first step towards land use planning that protects the environment.

\section{Materials and methods}

In the present study, consumption of resources, production of emissions, environmental quality standards and the capacity of ecosystems to provide resources and absorb the emissions were evaluated in an area of study. The study area coincided with the Province of Bari (Figure 1) located in Southern Italy. The province covers $5138.20 \mathrm{~km}^{2}$ (513,820 ha) and has a resident population of approximately $1,590,000$.

The environmental pressures and environmental carrying capacity of the Province of Bari were assessed.

\section{Evaluation of environmental pressures}

In the first phase, environmental pressures (resource flows, air emissions, water discharges and waste) were analysed and quantified through consultation of technical documents (Puglia Region, 2009; ARPA Puglia, 2009; ARPA Puglia, 2010) and databases (ISPRA, 2005). The data relating to consumption and emissions in the study area were processed using an appropriate set of environmental indicators (Table 1). These indicators are those most commonly used in the technical and scientific literature (Graymore et al., 2010; ARPA Puglia, 2010; Liu and Borthwick, 2011) and legislation (European Commission, 2009) because they represent the ecological dynamics and describe environmental problems.

The water consumed in the Province of Bari comes from aquifers (42.2\%), provincial and extra-provincial surface waters (29.6\%) and extra-provincial sources (28.2\%) (Puglia Region, 2009). The external provincial water supply is ensured by a complex aqueduct system built at the beginning of the twentieth century (Acquedotto Pugliese). Water consumption covers drinking water (61.6\%), agricultural use (32\%) and industry (6.4\%) (Puglia Region, 2009).

In the Province of Bari, there are several energy production plants powered by fossil and renewable sources that produce a surplus over demand. The electricity consumed by these activities (agriculture, industry, residential, tertiary) in the Province of Bari is approximately 4600 GWh (ARPA Puglia, 2010).

The area occupied by urban, industrial and agriculture in the Province of Bari is growing steadily (ARPA Puglia, 2009). The consumption of land, although often reversible, causes the degradation of soil that is removed from its natural function (European Commission, 2006). The land area given over to agricultural activities, residential areas, industrial sites and quarries in the Province of Bari is approximately 431,678 ha (ARPA Puglia, 2009), i.e. $84 \%$ of the total area.

The Province of Bari is also characterised by the presence of numerous protected areas which interest an area of approximately 138,724 ha, i.e. $27 \%$ of the total area (ARPA Puglia, 2010): national parks (Alta Murgia and Gargano), regional parks (Lama Balice, Lakes of Conversano and Gravina Monsignore) and sites of importance to the community (Murgia dei Trulli, Bosco Difesa Grande, etc.). The protect- 
ed areas of the province of Bari are characterised by the presence of agro-livestock activities that constitute the biggest source of employment for the local population.

Fertilisers are used in rural areas (mineral fertilisers, organic fertilisers, soil conditioners, correctives) that have a positive impact on the chemical-physical and microbiological characteristics of the soil. However, excessive fertilisation can at the same time cause pollution of groundwater and eutrophication of surface waters. In the Province of Bari, 157,065 tonnes of fertilisers are used (ARPA Puglia, 2009) that, assuming a nitrogen content equal to $5 \%$, means the application on agricultural soil of 7853 tonnes of nitrogen.

Annual emissions in the atmosphere of $\mathrm{CO}_{2}$, NOx, PM2.5, PM10, benzene, ammonia, dioxins and furans are set out in the National Inventory of Emissions to Atmosphere of the ISPRA (2005). This is the most comprehensive, consistent and transparent source of information on emissions at a regional and a provincial level.

The Province of Bari has 32 wastewater treatment plants with a water discharge flow of 550,800 m³/day (Puglia Region, 2002) amounting to $201 \mathrm{Mmc} / \mathrm{year}$. The wastewater treatment plants ensure that the physical-chemical and microbiological quality of discharge conforms with that set out in current EU (European Commission, 1991) and national (Italian Regulation, 2006) legislation. The resident population in the Province of Bari produces 831,998 tons/year of municipal solid waste and production activities are the source of 602,315 tons/year of special waste (ARPA Puglia, 2010) with a consequent annual production pro capita of $900 \mathrm{~kg} / \mathrm{year}$. Differentiated waste collection is $18 \%$ of the total municipal solid waste generated (ARPA Puglia, 2010).

Environmental carrying capacity

In the second phase of the study, the environmental carrying capacity of the Province of Bari was evaluated by estimating the critical flow of resources, emissions, water discharge and waste (Table 2). The critical flows have been identified both on the basis of objective data related to resource availability, and scientific and regulatory environmental quality standards.

The critical flows were identified through the methodological procedures described below and are associated with each environmental indicator (Table 3).
Sustainable consumption of resources: water, electricity, soil, fertilisers

Consumption of water resources is sustainable when it does not exceed $60 \%$ of average annual water body recharge. This threshold protects the quality status of the water, of the landscape and of the natural features of water bodies (Smakhtin et al., 2005). The water bodies of the Province of Bari are the Murge hydrogeological units and the artificial Locone dam that intercepts the waters of the stream of the same name.

The annual recharge of water bodies in the Province of Bari has been calculated on the basis of hydrogeological and hydrological balance and is equal to $1068 \mathrm{Mmc}$ for the Murge aquifer (Lattarulo et al., 2001) and $8 \mathrm{Mmc}$ for the Locone dam (Ranieri and Lagrotta, 2003). The flow of water resources is critical and amounts to $645 \mathrm{Mmc} / \mathrm{year}$.

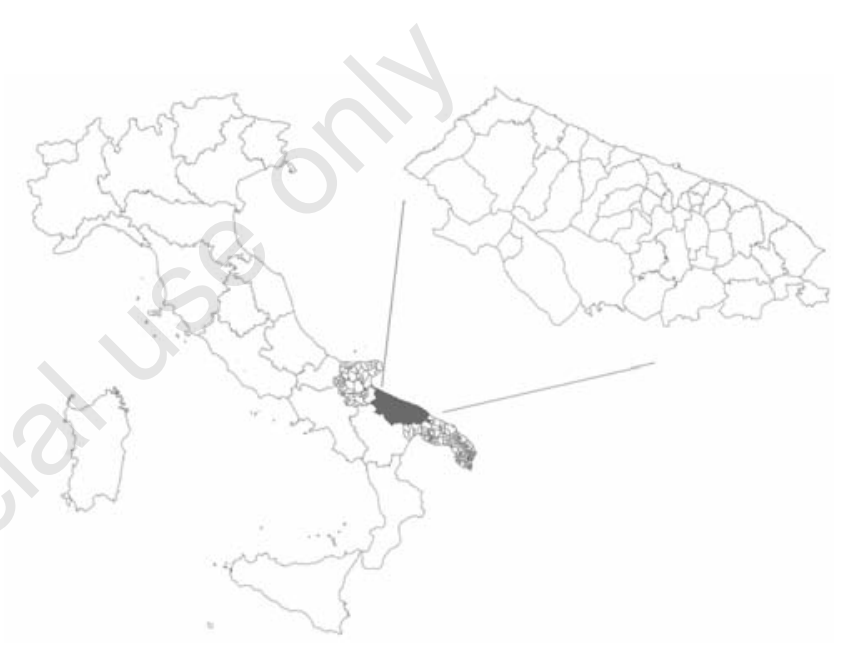

Figure 1. Province of Bari.

Table 1. Environmental indicators used in the sampling area (Province of Bari).

\begin{tabular}{llccc} 
Indicator & & Flow $\left(p_{i}\right)$ & Units of measurement & Bibliographic source \\
1 & Annual consumption of water resources & 419 & Mcm/year & Puglia Region, 2009 \\
2 & Annual consumption of electricity per capita & 2800 & kWh inhabitant/year & ARPA Puglia, 2010 \\
\hline 3 & Utilized land area & 431,678 & ha & ARPA Puglia, 2009 \\
4 & Unprotected land area & 375,096 & ha & ARPA Puglia, 2010 \\
\hline 5 & Nitrogen applied annually to agricultural soil & 7853 & t/year & ARPA Puglia, 2009 \\
6 & CO annual emissions & $3,390,925$ & t/year & ISPRA, 2005 \\
\hline 7 & NOx annual emissions & 21,643 & t/year & ISPRA, 2005 \\
8 & PM2.5 annual emissions & 3069 & t/year & ISPRA, 2005 \\
\hline 9 & PM10 annual emissions & 3588 & t/year & ISPRA, 2005 \\
10 & Dioxins and furans annual emissions & 4 & g-TEQ/year & ISPRA, 2005 \\
\hline 11 & Benzene annual emissions & 280 & t/year & ISPRA, 2005 \\
12 & Wastewater annual emissions & 201 & Mmc/year & Puglia Region, 2002 \\
\hline 13 & Annual production of solid waste per capita & 900 & \% & ARPA Puglia, 2010 \\
14 & Percentage undifferentiated waste collection & 82 & & ARPA Puglia, 2010 \\
\hline
\end{tabular}


Table 2. Critical flow of resources/emissions in sampling area (Province of Bari).

\begin{tabular}{|c|c|c|c|c|}
\hline Indicator & $\begin{array}{l}\text { Determination } \\
\text { of the critical flow }\end{array}$ & Critical flow $\left(c_{i}\right)$ & $\begin{array}{l}\text { Units of } \\
\text { measurement }\end{array}$ & $\begin{array}{l}\text { Bibliographic } \\
\text { source }\end{array}$ \\
\hline 1 Available water resources & $\begin{array}{l}\text { Bibliographic target: } 60 \% \text { of annual } \\
\text { water bodies recharge }\end{array}$ & 645 & Mmc/year & $\begin{array}{l}\text { Lattarulo et al., } \\
\text { 2001; Smakhtin et al., 2005; } \\
\text { Ranieri and Lagrotta, } 2003\end{array}$ \\
\hline $\begin{array}{l}2 \text { Sustainable energy consumption } \\
\text { per capita }\end{array}$ & Bibliographic target & 12,000 & kWh inhabitant/year & Graymore et al., 2010 \\
\hline 3 Maximum modified land area & $\begin{array}{l}\text { Bibliographic target: } \\
80 \% \text { of total land area }\end{array}$ & 411,064 & ha & Graymore et al., 2010 \\
\hline 4 Maximum unprotected land area & $\begin{array}{l}\text { Bibliographic target: } \\
75 \% \text { of total land area }\end{array}$ & 385,373 & ha & Graymore et al., 2010 \\
\hline $\begin{array}{ll}5 & \text { Maximum annual nitrogen } \\
\text { supply to agricultural soil }\end{array}$ & $\begin{array}{l}\text { Bibliographic target compared } \\
\text { to territorial extension }\end{array}$ & 4510 & tyear & BUWAL, 1996 \\
\hline $6 \quad \mathrm{CO}_{2}$ maximum annual emissions & $\begin{array}{l}\text { Legislative target: } \\
-20 \% \text { of } 1990 \text { emissions }\end{array}$ & $4,564,857$ & tyear & European Commission, 2008a \\
\hline 7 NOx maximum annual emissions & $\begin{array}{l}\text { Legislative target: } \\
-40 \% \text { of } 2000 \text { emissions }\end{array}$ & 15,027 & tyear & BUWAL, 2005a \\
\hline 8 PM2.5 maximum annual emissions & $\begin{array}{l}\text { Bibliographic target compared } \\
\text { to territorial extension }\end{array}$ & 865 & t/year & BUWAL, 2005b \\
\hline 9 PM10 maximum annual emissions & $\begin{array}{l}\text { Bibliographic target compared } \\
\text { to territorial extension }\end{array}$ & 1493 & tyear & BUWAL, 2005b \\
\hline 10 Dioxins and furans maximum & $\begin{array}{l}\text { Bibliographic target compared } \\
\text { to territorial extension } \\
\text { annual emissions }\end{array}$ & 4.3 & g-TEQ/year & BAG et al., 2003 \\
\hline 11 Benzene annual emissions & $\begin{array}{l}\text { Bibliographic target compared } \\
\text { to territorial extension }\end{array}$ & 65 & tyear & BUWAL, 2003 \\
\hline $\begin{array}{l}12 \text { Wastewater maximum } \\
\text { annual emissions }\end{array}$ & $\begin{array}{l}\text { Bibliographic target: - } 15 \% \text { current } \\
\text { water discharge }\end{array}$ & 171 & Mmc/year & Dal Sasso, 2001 \\
\hline $\begin{array}{l}13 \text { Maximum annual production } \\
\text { of solid waste per capita }\end{array}$ & Bibliographic target & 750 & $\mathrm{~kg}$ inhabitand/year & Graymore et al., 2010 \\
\hline $\begin{array}{l}14 \text { Maximum percentage } \\
\text { undifferentiated waste collection }\end{array}$ & Legislative target & 35 & $\%$ & Italian Regulation, 2006 \\
\hline
\end{tabular}

Table 3. Assessment of the environmental sustainability on regional scale in the sampling area (Province of Bari).

\begin{tabular}{|c|c|c|c|c|c|c|}
\hline Indicator (N) & Flow $\left(d_{i}\right)$ & Critical flow $\left(c_{i}\right)$ & Units of measurement & $p_{i}$ & $r_{j}$ & $r_{j}^{\wedge} 2$ \\
\hline 1 Annual water resources consumption & 419 & 645 & Mmc/year & 0.35 & 0.65 & 0.42 \\
\hline 2 Annual electricity per capita consumption & 2800 & 12,000 & kWh inhabitant/year & 0.77 & 0.23 & 0.05 \\
\hline 3 Land area utilized & 431,678 & 411,064 & ha & -0.05 & 1.05 & 1.10 \\
\hline 4 Unprotected land area & 375,096 & 385,373 & ha & 0.03 & 0.97 & 0.95 \\
\hline 5 Nitrogen applied annually to agricultural soil & 7853 & 4510 & tyear & -0.74 & 1.74 & 3.03 \\
\hline $6 \quad \mathrm{CO}_{2}$ annual emissions & $3,390,925$ & $4,564,857$ & tyear & 0.26 & 0.74 & 0.55 \\
\hline 7 Nox annual emissions & 21,643 & 15,027 & tyear & -0.44 & 1.44 & 2.07 \\
\hline 8 PM2.5 annual emissions & 3069 & 865 & tyear & -2.55 & 3.55 & 12.59 \\
\hline $9 \quad$ PM10 annual emissions & 3588 & 1493 & tyear & -1.40 & 2.40 & 5.78 \\
\hline 10 Dioxins and furans annual emissions & 4 & 4.3 & g-TEQ/year & 0.07 & 0.93 & 0.87 \\
\hline 11 Benzene annual emissions & 280 & 65 & tyear & -3.31 & 4.31 & 18.56 \\
\hline 12 Wastewater annual emissions & 201 & 171 & Mmc/year & -0.18 & 1.18 & 1.38 \\
\hline 13 Annual production of solid waste per capita & 900 & 750 & kg inhabitant/year & -0.20 & 1.20 & 1.44 \\
\hline \multirow[t]{2}{*}{14 Percentage of undifferentiated waste collection } & 82 & 35 & $\%$ & -1.34 & 2.34 & 5.49 \\
\hline & & & & & Total & 54.28 \\
\hline
\end{tabular}


The annual pro capita energy consumption was defined as being sustainable up to $12,000 \mathrm{kWh} / \mathrm{ab}$ year (Graymore et al., 2010) making this the critical flow of energy in the study area.

The percentage of land that can be modified by man's agricultural, industrial, residential and service activities must not exceed $80 \%$ of the total land area (Graymore et al., 2010) in order to protect soil biodiversity and bio-geo-chemical function. The critical flow of land in the Province of Bari is, therefore, 411,064 ha.

Portions of land that are protected for species, habitat conservation and the landscape environment must be over $25 \%$ of the total land area (Graymore et al., 2010). The land area of the province of Bari is not subject to protection and should, therefore, be up to 385,373 ha. For Switzerland, the maximum amount of nitrogen added to the arable soil by fertilisation and irrigation has been reported to be 17,000 tonnes/year (BUWAL, 1996). Considering the ratio of the operative agricultural area of Switzerland compared with that of the Province of Bari the critical flow of nitrogen in the study area is 4510 tons/year.

Emissions assimilated from the environment: $\mathrm{CO}_{2}, \mathrm{NOx}, \mathrm{PM} 10$, PM2.5, benzene, dioxins and furans

The capacity of the atmosphere to absorb pollutants without compromising air quality depends heavily on weather conditions, and soil and emissions' characteristics (Goyal and Chalapati Rao, 2007).

The climate and energy legislative package adopted by the European Parliament has imposed a $20 \%$ reduction in $\mathrm{CO}_{2}$ emissions with respect to those of 1990; therefore, the critical flow of $\mathrm{CO}_{2}$ in the Province of Bari is 4,564,857 tons/year.

The critical flows of NOx, PM10, PM2.5, benzene, dioxins and furans have been proposed by BUWAL (2003, 2005a, 2005b) and BAG (2003) for Switzerland. Given their technical and scientific value, these critical flows have been adopted in this study and compared to the total area of the Province of Bari.

\section{Water discharge that can be assimilated by the environment}

The wastewater produced by households and industrial activities are treated in sewage treatment plants before being discharged into the environment. Treatment of wastewater reduces the concentration of pollutants in the water and avoids environmental contamination. The assimilation of wastewater pollutants by the receiving water body depends on the hydrodynamic and biological characteristics of natural waters (Tett et al., 2007) and chemical-physical properties of pollutants. The flow of water discharge must, however, be reduced by $15 \%$ (Dal Sasso, 2001) to avoid degradation of inland surface waters, coastal waters and groundwater quality. The critical flow of wastewater in the Province of Bari is $171 \mathrm{Mmc}$.

\section{Production and sustainable waste management}

Waste management must be performed according to the principles of precaution, prevention and sustainability (European Commission, 2008b). It is, therefore, necessary to reduce the production of waste, increase separate waste collection and the subsequent recycling, and avoid landfill.

The critical flow of waste per capita was set at $750 \mathrm{~kg}$ inhabitants/ year (Graymore et al., 2010) with a minimum rate of separate waste collection of 65\% (Italian Regulation, 2006).

\section{Evaluation of the environmental sustainability on a regional scale}

In the third phase of the study, we determined the environmental sustainability of current land use in the Province of Bari by comparing environmental pressures (flows of consumption/emissions) and environmental carrying capacity (critical flows of consumption/emission).

The comparison was made using the method developed by Liu and
Borthwick (2011) that allows a precise quantitative assessment of territorial sustainability. The method is based on the direct comparison between flows $\left(p_{i}\right)$ and critical flows $\left(c_{i}\right)$ both for each indicator and overall.

The direct comparison between flows and critical flows for each indicator assesses the surplus (+) or deficit (-) of carrying capacity with respect to environmental pressure $(d)$ in relation to each environmental aspect considered (water consumption, energy consumption, etc.) according to the formula:

$$
d_{i}=1-\left(\frac{p_{i}}{c_{i}}\right)
$$

where $d_{i}>0$ each environmental pressure is lower than carrying capacity while when $d_{i}<0$ each environmental pressure exceeds the carrying capacity of the study area. The overall comparison between flows and critical flows assesses the surplus (+) or deficit (-) of the total carrying capacity with respect to environmental pressure $(D)$ in the study area according to the formula:

$$
D=1-\sqrt{\frac{\sum\left(r_{j}\right)^{2}}{N}}
$$

where $N$ is the number of indicators and $r_{j}$ the relationship between environmental pressures $\left(p_{i}\right)$ and carrying capacity $\left(c_{i}\right)$ for each indicator. When $D>0$, the environmental pressures are lower than the total carrying capacity of the study area and when $D<0$, the environmental pressures are higher than the carrying capacity.

\section{Results and discussion}

This study synthesised a numerical value with the overall ratio between environmental pressures and carrying capacity in the study area. In the Province of Bari, the overall deficit of carrying capacity with respect to environmental pressure is -0.97 . To reset the modest ecological deficit it is necessary to reduce the overall environmental pressure to the maximum carrying capacity of the territory.

The methodology also evaluated the surplus or deficit of the load carrying capacity according to single environmental pressures. This approach identifies those environmental pressures that exceed the load capacity and helps formulate the technical options and strategies to be adopted in the development of the area necessary to reduce the total environmental load.

An analysis of results showed that the overall deficit of carrying capacity in the study area is mainly related to environmental pressures generated by the high emission of benzene and particulate matter (PM2.5 and PM10) and the low percentage of separate waste collection. The environmental pressures related to energy and water consumption and atmospheric emissions of dioxins and furans are lower than the carrying capacity.

The methodology can, therefore, be used in the context of advanced territorial planning to assess the environmental load generated by local transformation to verify how far maximum environmental carrying capacity will be respected.

Assessment of territorial environmental sustainability using the methodology developed and applied in the study area can support the choices of transformation and land use of the area, providing a significant boost to sustainable development. 


\section{Conclusions}

This study has allowed us to develop and apply appropriate analytical methodology to estimate the carrying capacity of ecosystems and assess environmental sustainability in the study area. The proposed methodology broadens our understanding of the ecological balance of the area through a comparison of environmental pressures resulting from human activities and the carrying capacity of support ecosystems. Application of this methodology in the Province of Bari allowed an individual and global analysis of the interchange between human activities and ecosystems to identify the environmental pressures that may affect ecosystem stability. The proposed methodology can also be applied to numerically compare the ecological balance of different areas to ensure its environmental sustainability and establish the most appropriate policies for the exchange of resources. The accuracy of the methodology can be increased through the integration of environmental indicators and details with estimates of the capacity of ecosystems to provide resources and absorb the emissions. An understanding of the capacity of ecosystems within a particular area to provide resources and absorb emissions, effluents and waste is a useful guide to modern planning criteria conforming to socio-economic and environmental protection needs. Through evaluation of territorial environmental sustainability based on carrying capacity of ecosystems it is possible to assess in advance the effects of territorial changes on the environmental balance. The proposed methodology, therefore, assesses the current or future sustainability of land use in order to avoid irreversible changes to the balance of ecosystem status and to develop guidelines for environmental and socio-economical sustainable territorial development.

\section{References}

ARPA Puglia (Regional Agency for Environmental Prevention and Protection). 2009. State of the Environment - Report 2009. Available from: http://www.arpa.puglia.it/web/guest/arpa_home

ARPA Puglia (Regional Agency for Environmental Prevention and Protection). 2010. State of the Environment - Report 2010. Available from: http://www.arpa.puglia.it/web/guest/arpa_home

Baldwin J.H. 1985. Environmental planning and management. Westview Press, Boulder, Colorado, USA.

Bettini V. 1986. Elementi di analisi ambientale per urbanisti. ClupClued, Milano, Italy.

BAG (Bundesamt für Gesundheit), BUWAL (Bundesamt für Umwelt, Wald und Landschaft), BLW (Bundesamt für Landwirtschaft), BVET (Bundesamt für Veterinärwesen), seco (Staatssekretariat für Wirtschaft), EDA (Eidgenössisches Departement des Äussern). 2003. Das Vorsorgeprinzip aus schweizerischer und internationaler Sicht. Synthesepapier der interdepartementalen Arbeitsgruppe "Vorsorgeprinzip", August 2003. Bundesamt für Gesundheit (BAG), Bern, Switzerland.

BUWAL (Bundesamt für Umwelt, Wald und Landschaft). 1996. Strategie zur Reduktion von Stickstoffemissionen. Bundesamt für Umwelt, Wald und Landschaft (BUWAL). Bern, Switzerland.

BUWAL (Bundesamt für Umwelt, Wald und Landschaft). 2003. Benzol in der Schweiz. Bundesamt für Umwelt, Wald und Landschaft (BUWAL). Bern, Switzerland.

BUWAL (Bundesamt für Umwelt, Wald und Landschaft). 2005a. Emissionen gemäss Excel-File Tab. 256+rev. NC4 Stand 9. Bundesamt für Umwelt, Wald und Landschaft (BUWAL). Bern, Switzerland.

BUWAL (Bundesamt für Umwelt, Wald und Landschaft). 2005b. Weiterentwicklung des Luftreinhaltekonzepts: Stand,
Handlungsbedarf, mögliche Massnahmen. SRU 379. Bundesamt für Umwelt, Wald und Landschaft (BUWAL). Bern, Switzerland.

Cai Y.M., Zheng W.Y., Zhang X.L., Jia K.J., Yang F. 2003. Preliminary research on environment impact assessment of land use planning. Prog. Geogr. 22:567-75.

Castoldi N., Bechini L. 2010. Integrated sustainability assessment of cropping systems with agro-ecological and economic indicators in northern Italy. Eur. J. Agr. 32:59-72.

Clarke A.L. 2002. Assessing the carrying capacity of the Florida Keys. Popul. Environ. 23:405-18.

Colantonio R., Galli A. 2006. Integrated indicators in environmental planning: methodological considerations and applications. Ecol. Indic. 6:228-37.

Daily G.C. 1997. Nature's services: societal dependence on natural ecosystems. Island Press, Washington, DC, USA.

Dale V.H., Beyeler S.C. 2001. Challenges in the development and use of ecological indicators. Ecol. Indic. 1:3-10.

Dal Sasso P. 2001. Verifica di adattabilità del bilancio ecologico a fabbricati agricoli di esercizio. Atti del Convegno dell'Associazione Italiana di Ingegneria Agraria su "Ingegneria Agraria per lo sviluppo dei paesi del mediterraneo", Vieste, Italy, pp 1-11.

Daly H.E. 1991. Steady state economics. Island Press, Washington, DC, USA.

European Commission. 1991. Urban wastewater treatment, 91/271/EC. In: Official Journal, L 135/40/1991, pp 40-52.

European Commission. 2006. Thematic Strategy for Soil Protection, COM(2006)231. Proposal for a directive, COD 2006/0086.

European Commission. 2008a. Climate and Energy Package, $\operatorname{COM}(2008) 30$.

European Commission. 2008b. Waste Framework Directive, 08/98/EC. In: Official Journal, L 312/3/2008, pp 3-30.

European Commission. 2009. EMAS Regulation, Reg. no. 1221/2009. In: Official Journal, L 342/1/2009.

Franzese P.P., Riccio A., Scopa A. 2003. Valutazione della sostenibilità ambientale: verso un approccio ecodinamico. Biologi Italiani 7:5860.

Godschalk D.R., Parker F.H. 1975. Carrying capacity: a key to environmental planning. J. Soil Water Conserv. 30:160-5.

Goyal S.K., Chalapati Rao C.V. 2007. Air assimilative capacity-based environment friendly sitting of new industries: a case study of Kochi region, India. J. Environ. Manage. 84:473-83.

Graymore M.L.M., Sipe N.G., Rickson R.E. 2010. Sustaining human carrying capacity: a tool for regional sustainability assessment. Ecol. Econ. 69:459-68.

Harmaajarvi I. 2000. EcoBalance model for assessing sustainability in residential areas and relevant case studies in Finland. Environ. Impact Asses. 20:373-80.

Holden E. 2004. Ecological footprint and sustainable urban form. Housing Built Environ. 19:91-109.

Holling C.S., Berkes F., Folke C. 2000. Science, sustainability and resource management. Linking social and ecological systems: management practices and social mechanisms for building resilience. Cambridge University Press, Cambridge, UK.

ISPRA (Italian Institute for Environmental Protection). 2005. INEMAR Database. Available from: http://www.inemar.eu/xwiki/bin/view/ Inemar/WebHome

Italian Regulation. 2006. Norme in materia ambientale, LD 152/2006. In: Official Journal No. 88/2006.

Kang P., Xu L. 2010. The urban ecological regulation based on ecological carrying capacity. Procedia Environ. Sci. 2:1692-700.

Khanna P., Babu P.R., George M.S. 1999. Carrying-capacity as a basis for sustainable development. A case study of National Capital Region in India. Progr. Plan. 52:101-66.

Komatsu Y., Tsunekawa A., Ju H. 2005. Evaluation of agricultural sus- 
tainability based on human carrying capacity in drylands - a case study in rural villages in Inner Mongolia, China. Agr. Ecosyst. Environ. 108:29-43.

Lane M. 2010. The carrying capacity imperative: assessing regional carrying capacity methodologies for sustainable land-use planning. Land Use Policy 27:1038-45.

Lattarulo 0., Portoghese I., Vurro M., Perrino V.M. 2001. L'evoluzione dell'inquinamento da intrusione salina nell'acquifero murgiano. Atti del Convegno Nazionale "Sorella Acqua per il 2000, conoscerla per salvarla", Lions, Bari, Italy.

Liu R.Z., Borthwick A.G.L. 2011. Measurement and assessment of carrying capacity of the environment in Ningbo, China. J. Environ. Manage. 92:2047-53.

Maffiotti A., Borasi L., Molinari C., Chiodi E., Puccio L. 2008. Il bilancio ambientale territoriale. Ingegneria Ambientale 37:554-5.

Marull J., Pino J., Mallarach J.M., Cordobilla M.J. 2007. A land suitability index for strategic environmental assessment in metropolitan areas. Landscape Urban Plan. 81:200-12.

Monfreda C., Wackernagel M., Deumling D. 2004. Establishing national natural capital accounts based on detailed ecological footprint and biological capacity assessments. Land Use Policy 21:231-46.

Morrissey J., O'Reagan B., Moles R. 2006. Development of urban sustainability indicators and indices evaluation of the sustainability of Irish settlement patterns. In: Proc. 12th Ann. Int. Sustain. Develop. Res. Conf., Hong Kong, China.

Ng K.L., Obbard J.P. 2004. Strategic environmental assessment in Hong Kong. Environ. Int. 31:483-92.

Niccolucci V., Bastianoni S., Tiezzi E.B.P., Wackernagel M., Marchettini N. 2009. How deep is the footprint? A 3D representation. Ecol. Model. 220:2819-23.

Niemi E., McDonald M. 2004. Application of ecological indicators. Annu. Rev. Ecol. Evol. S. 35:89-111.

Odum, H.T. 1988. Energy, environment and public policy. A guide to the analysis of systems. UNEP Regional Seas Report and Studies No. 95. Available from: http://www.unep.org/regionalseas/ publications/reports/RSRS/pdfs/rsrs095.pdf

Odum H.T. 1996. Environmental accounting: Emergy and environmental decision making. Wiley, London, UK.

Oh K., Jeong Y., Lee D., Lee W., Choi J. 2005. Determining development density using the Urban Carrying Capacity Assessment System. Landscape Urban Plan. 73:1-15.

Papageorgiou K., Brotherton I. 1999. A management planning framework based on ecological, perceptual and economic carrying capacity: the case study of Vikos-Aoos National Park, Greece. J. Environ. Manage. 56:271-84.

Puglia Region. 2002. Water Director Plan. Available from: http:/www. regione.puglia.it/

Puglia Region. 2009. Water Protection Plan. [In Italian]. Available from: http://www.regione.puglia.it/ index.php?page=documenti \&id=29\&fs_id=1857\&opz=downfile

Ranieri M, Lagrotta E. 2003. Il sistema idrico in Puglia. Ministero delle Infrastrutture e dei Trasporti, Bari, Italy.

Rajaram T., Das A. 2011. Screening for EIA in India: enhancing effectiveness through ecological carrying capacity approach. J. Environ. Manage. 92:140-8.

Scheffer M., Carpenter S., Foley J.A., Folke C., Walker B. 2001. Catastrophic shifts in ecosystems. Nature 413:591-6.
Smakhtin V., Revanga C., Doll P. 2005. Taking into account environmental water requirements in global-scale water resources assessments. International Water Management Institute (IWMI), Battaramulla, Sri Lanka. Available from: http:/www.iwmi.cgiar.org/ assessment/files/pdf/publications/researchreports/carr2.pdf

Steiner F., McSherry L., Cohen J. 2000. Land suitability analysis for the upper Gila River watershed. Landscape Urban Plan. 50:199-214.

Tang J.W., Ye W.H. 1998. Study on environmental carrying capacity and its quantification. China Environ. Sci. 18:227-30. [Article in Chinese].

Tett P., Portilla E., Inall M., Gillibrand P., Gubbins M., Amundrod T. 2007. Modelling the assimilative capacity of Sea-Lochs (Final Report on SARF 012). Scottish Aquaculture Research Forum (SARF), Pitlochry, UK. Available from: http://www.sarf.org.uk/Project\% 20Final\%20Reports/SARF012\%20-\%20Final\%20Report.pdf

United Nations Economic Commission for Europe. 1991. The Espoo Convention. Available from: http://www.unece.org/env/eia/eia.html

Tiezzi E., Marchetti N. 2003. Calcolo dell'impronta ecologica della Provincia di Cagliari e dei suoi quattro subambiti. Firenze University Press (Pubblicazioni Ce.S.E.T.), Firenze, Italy. Available from: http://www.fupress.net/index.php/ceset

Turnhout E., Hisschemoller M., Eijsackers H. 2007. Ecological indicators: between the two fires of science and policy. Ecol. Indic. 7:21528.

Ulgiani S., Odum H.T., Bastianoni S. 1994. Emergy use, environmental loading and sustainability. An emergy analysis of Italy. Ecol. Model. 73:215-78.

Van Cauwenbergh N., Biala K., Bielders C., Brouckaert V., Franchois L., Garcia Cidad V. 2007. SAFE - a hierarchical framework for assessing the sustainability of agricultural systems. Agr. Ecosyst. Environ. 120:229-42.

Wackernagel M., Rees W. 1996. Our ecological footprint: reducing human impact on the Earth. New Society Publishers, Gabriola Island, Canada.

Wackernagel M., Rees W. 1997. Perceptual and structural barriers to investing in natural capital: economics from an ecological footprint perspective. Ecol. Econ. 20:2-24.

Wiek A., Binder C. 2005. Solution spaces for decision-making - a sustainability assessment tool for city-regions. Environ. Impact Asses. 25:589-608.

Wiggering H., Muller F. 2004. Umweltziele und Indikatoren. Springer, Berlin, Germany.

Word Commission on Environment and Development. 1987. Our Common Future, A/RES/42/187 Report, 1987. Oxford University Press, Oxford, UK.

Yin Y., Liu X., Wang J., Cheng J. 2010. Application of environmental carrying capacity in regional environmental impact assessment: a case study on Shandong Rencheng economic development area. J. Environ. Techn. Eng. 3:74-9.

Yu D.L., Mao H.Y. 2002. Regional carrying capacity: case studies of Bohai Rim area. J. Geogr. Sci. 12:177-85.

Zahm F., Viaux P., Girardin P., Vilain L., Mouchet C. 2006. Farm sustainability assessment using the IDEA method: from the concept of farm sustainability to the case studies on French farms. Proceedings and Outputs of the first Symposium of the International Forum on Assessing Sustainability in Agriculture (INFASA), Bern, Switzerland, 16:271-81. 